\section{Editors-in-Chief}

H.-W. Denker, Essen

A.W. English, Atlanta, Ga.

Cells
Tissues
Organs

\title{
in vivo, in vitro
}

Founded 1945 as 'Acta Anatomica' by R. Chambers, G. Glimstedt, T. Peterfi and G. Wolf-Heidegger

Continued 1962-1974 by E.A. Boyden, 1955-1980 by A. Delmas,

$1972-1980$ by F. Walberg, $1945-1980$ by G. Wolf-Heidegger,

1981-1988 by R. O’Rahilly, Davis, Calif., 1989-1990 by G.E. Goslow, Jr., Providence, R.I.,

1981-1992 by W. Lierse, Hamburg, since 1992 by H.-W. Denker, Essen, and

A.W. English, Atlanta, Ga., continued 1999 as 'Cells Tissues Organs' by H.-W. Denker, Essen, and A.W. English, Atlanta, Ga.

\section{Associate Editors}

\section{Developmental Biology}

D. Newgreen, Melbourne

E-Mail: don.newgreen@mcri.edu.au

Stem Cells and Tissue Engineering

A. Bader, Leipzig

E-Mail: augustinus.bader@bbz.uni-leipzig.de

S.F. Badylak, Pittsburgh, Pa.

E-Mail: badylaks@msx.upmc.edu

A. Müller, Würzburg

E-Mail: albrecht.müller@mail.uni-wuerzburg.de

A. Ratcliffe, San Diego, Calif.

E-Mail: anthonyratcliffe@synthasome.com

A.M. Wobus, Gatersleben

E-Mail: wobusam@ipk-gatersleben.de

\section{Neurosciences}

M. Frotscher, Freiburg i.Br.

E-Mail: frotsch@sun2.ruf.uni-freiburg.de

W.L. Neuhuber, Erlangen

E-Mail: winfried.neuhuber@rzmail.uni-erlangen.de

Functional Anatomy and

Biomechanics

Luigi Gallo, Zurich

E-Mail: luigi@zui.unizh.ch

R. Putz, Munich

E-Mail: putz@anat.med.uni-muenchen.de

\section{Editorial Board}

F. Beck, Leicester

A.L. Boskey, New York, N.Y.

R.C. Burghardt, College Station, Tex.

G. Burnstock, London

F. Eckstein, Salzburg

A.C. Enders, Davis, Calif.

C. Farnum, Ithaca, N.Y.

R.H.W. Funk, Dresden

N.E. Fusenig, Heidelberg
A. Gibson, Phoenix, Ariz.

M. Glickstein, London

J.W. Hermanson, Ithaca, N.Y.

C.J. Kirkpatrick, Mainz

P. Köpf-Maier, Berlin

W. Kummer, Giessen

J.W. Lichtman, Cambridge, Mass.

K.G. Marra, Pittsburgh, Pa.

O. Ohtani, Toyama
P.J. Reier, Gainesville, Fla.

R. Roy, Los Angeles, Calif.

R. Segal, Chapel Hill, N.C.

F. Sinowatz, Munich

M. Sittinger, Berlin

T. Skutella, Tübingen

G.B. Stark, Freiburg i.Br.

E. Thompson, Melbourne

C.G. Widmer, Gainesville, Fla. 


\section{No. 1-4}

Chemistry and Biology of Mineralized Tissues

Guest Editors: Bonewald, L.F. (Kansas City, Mo.); Krebsbach, P.H (Ann Arbor, Mich.)

5 Introduction

Bonewald, L.F. (Kansas City, Mo.); Krebsbach, P.H. (Ann Arbor, Mich.)

6 Time Lapse Imaging Techniques for Comparison of Mineralization Dynamics in Primary Murine Osteoblasts and the Late Osteoblast/Early Osteocyte-Like Cell Line MLO-A5

Dallas, S.L.; Veno, P.A.; Rosser, J.L.; Barragan-Adjemian, C. (Kansas City, Mo.); Rowe, D.W.; Kalajzic, I. (Farmington, Conn.); Bonewald, L.F.

(Kansas City, Mo.)

12 The Composition of Bovine Peritubular Dentin: Matching TOF-SIMS, Scanning Electron Microscopy and Biochemical Component Distributions. New Light on Peritubular Dentin Function

Gotliv, B.A. (Rehovot); Veis, A. (Chicago, Ill.)

20 Mineral Deposition in the Extracellular Matrices of Vertebrate Tissues: Identification of Possible Apatite Nucleation Sites on Type I Collagen

Landis, W.J. (Rootstown, Ohio); Silver, F.H. (Piscataway, N.J.)

25 Potential Role of Proprotein Convertase SKI-1 in the Mineralization of Primary Bone

Gorski, J.P.; Huffman, N.T. (Kansas City, Mo.); Cui, C. (Lhasa); Henderson, E.P. (Kansas City, Mo.); Midura, R.J. (Cleveland, Ohio); Seidah, N.G. (Montreal, Que.)

33 Exercise Alters Mineral and Matrix Composition in the Absence of Adding New Bone

Kohn, D.H.; Sahar, N.D.; Wallace, J.M.; Golcuk, K.; Morris, M.D. (Ann Arbor, Mich.)

38 Avian Eggshell Structure and Osteopontin Chien, Y.-C. (Montreal, Que.); Hincke, M.T. (Ottawa, Ont.); McKee, M.D. (Montreal, Que.)

44 Role of Phosphate Groups in Inhibition of Calcium Oxalate Crystal Growth by Osteopontin

Hunter, G.K.; Grohe, B.; Jeffrey, S.; O’Young, J. (London, Ont.); Sørensen, E.S. (Aarhus); Goldberg, H.A. (London, Ont.)

51 Phosphorylation of Osteopontin Peptides Mediates Adsorption to and Incorporation into Calcium Oxalate Crystals

O’Young, J.; Chirico, S.; Al Tarhuni, N.; Grohe, B.; Karttunen, M.; Goldberg, H.A.; Hunter, G.K. (London, Ont.)

56 Inhibition of Phosphate-Induced Apoptosis in Resting Zone Chondrocytes by Thrombin Peptide 508

Zhong, M. (Atlanta, Ga.); Carney, D.H. (Galveston, Tex.); Ryaby, J.T. (Tempe, Ariz.); Schwartz, Z.; Boyan, B.D. (Atlanta, Ga.)

60 Effect of Dentin Phosphoprotein on Phosphate-Induced Apoptosis of Odontoblast-Like Cells

Fujisawa, R.; Mizuno, M.; Tamura, M. (Sapporo)
65 Osteoblast Differentiation Stage-Specific Expression of the Pyrophosphate-Generating Enzyme PC-1 Hatch, N.E.; Franceschi, R.T. (Ann Arbor, Mich.)

70 1,25-Dihydroxy Vitamin $D_{3}$ Is an Autocrine Regulator of Extracellular Matrix Turnover and Growth Factor Release via ERp60-Activated Matrix Vesicle Matrix Metalloproteinases Boyan, B.D.; Schwartz, Z. (Atlanta, Ga.)

75 Isolation of Calcospherulites from the Mineralization Front of Bone

Midura, R.J.; Vasanji, A.; Su, X.; Midura, S.B. (Cleveland, Ohio); Gorski, J.P. (Kansas City, Mo.)

80 Identification and Functional Analysis of Two Novel PAX9 Mutations

Wang, Y. (Dallas, Tex.); Wu, H. (Beijing); Wu, J. (Dallas, Tex.); Zhao, H.; Zhang, X. (Beijing); Mues, G.; D’Souza, R.N. (Dallas, Tex.); Feng, H. (Beijing); Kapadia, H. (Dallas, Tex.)

88 Autophagy: A New Phase in the Maturation of Growth Plate Chondrocytes Is Regulated by HIF, mTOR and AMP Kinase Srinivas, V.; Bohensky, J.; Shapiro, I.M. (Philadelphia, Pa.)

93 Activation of Sirt1 Decreases Adipocyte Formation during Osteoblast Differentiation of Mesenchymal Stem Cells Bäckesjö, C.-M.; Li, Y.; Lindgren, U.; Haldosén, L.-A. (Huddinge)

98 Identifying Promoter Elements Necessary for Enamelin Tissue-Specific Expression Papagerakis, P.; Hu, Y. (Ann Arbor, Mich.); Ye, L.; Feng, J.Q. (Dallas, Tex.); Simmer, J.P.; Hu, J.C.-C. (Ann Arbor, Mich.)

105 Tissue- and Cell-Specific Alternative Splicing of NFIC Lamani, E.; Wu, Y.; Dong, J.; Litaker, M.S. (Birmingham, Ala.); Acevedo, A.C. (Brasilia); MacDougall, M. (Birmingham, Ala.)

111 Lysosomal Protease Expression in Mature Enamel Tye, C.E.; Lorenz, R.L.; Bartlett, J.D. (Boston, Mass.)

115 Msx 1 Expression Regulation by Its Own Antisense RNA: Consequence on Tooth Development and Bone Regeneration Babajko, S.; Petit, S.; Fernandes, I.; Méary, F.; LeBihan, J.; Pibouin, L.; Berdal, A. (Paris)

122 Molecular Switches Involving Homeodomain Proteins, HOXA10 and RUNX2 Regulate Osteoblastogenesis Hassan, M.Q.; Saini, S.; Gordon, J.A.R.; van Wijnen, A.J. (Worcester, Mass.); Montecino, M. (Concepción); Stein, J.L.; Stein, G.S.; Lian, J.B. (Worcester, Mass.)

126 Differential Impact of Msx1 and Msx2 Homeogenes on Mouse Maxillofacial Skeleton

Berdal, A.; Molla, M.; Hotton, D.; Aïoub, M.; Lézot, F.; Néfussi, J.-R.; Goubin, G. (Paris)

133 Specific Residues of RUNX2 Are Obligatory for Formation of BMP2-Induced RUNX2-SMAD Complex to Promote Osteoblast Differentiation

Javed, A. (Worcester, Mass./Birmingham, Ala.); Afzal, F.; Bae, J.-S. (Worcester, Mass.); Gutierrez, S. (Concepción); Zaidi, K.; Pratap, J.; van Wijnen, A.J.; Stein, J.L.; Stein, G.S.; Lian, J.B. (Worcester, Mass.)

138 Activation of the Mitogen-Activated Protein Kinase Pathway by Bone Sialoprotein Regulates Osteoblast Differentiation Gordon, J.A.R.; Hunter, G.K.; Goldberg, H.A. (London, Ont.)

\section{KARGER}

Fax +41 613061234

E-Mail karger@karger.ch

www.karger.com
(C) 2009 S. Karger AG, Base

Access to full text and tables of contents, including tentative ones for forthcoming issues: www.karger.com/cto_issues 
144 Transcriptional Regulation of Osteoblasts

Franceschi, R.T.; Ge, C. (Ann Arbor, Mich.); Xiao, G. (Pittsburg, Pa.);

Roca, H.; Jiang, D. (Ann Arbor, Mich.)

153 The Potential Functional Interaction of Biglycan and WISP-1 in Controlling Differentiation and Proliferation of Osteogenic Cells

Inkson, C.A.; Ono, M.; Bi, Y.; Kuznetsov, S.A.; Fisher, L.W.; Young, M.F (Bethesda, Md.)

158 Progressive Ankylosis Gene (ank) Regulates Osteoblast Differentiation

Kirsch, T.; Kim, H.J.; Winkles, J.A. (Baltimore, Md.)

163 Mineralization and Expression of Col1 a1-3.6GFP Transgene in Primary Dental Pulp Culture

Balic, A.; Rodgers, B.; Mina, M. (Farmington, Conn.)

169 The Leucine-Rich Amelogenin Peptide Alters the Amelogenin Null Enamel Phenotype

Gibson, C.W.; Li, Y. (Philadelphia, Pa.); Daly, B.; Suggs, C.; Yuan, Z.

(Chapel Hill, N.C.); Fong, H. (Seattle, Wash.); Simmons, D. (Chapel Hill, N.C.); Aragon, M. (Philadelphia, Pa.); Kulkarni, A.B. (Bethesda, Md.); Wright, J.T. (Chapel Hill, N.C.)

175 Studies of the DMP1 57-kDa Functional Domain both in vivo and in vitro

Lu, Y. (Kansas City, Mo.); Qin, C.; Xie, Y. (Dallas, Tex.); Bonewald, L.F. (Kansas City, Mo.); Feng, J.Q. (Dallas, Tex.)

186 Distinct Compartmentalization of Dentin Matrix Protein 1 Fragments in Mineralized Tissues and Cells

Maciejewska, I.; Qin, D.; Huang, B.; Sun, Y.; Mues, G.; Svoboda, K. (Dallas, Tex.); Bonewald, L. (Kansas City, Mo.); Butler, W.T.; Feng, J.Q.; Qin, C. (Dallas, Tex.)

192 Blocking of Proteolytic Processing and Deletion of Glycosaminoglycan Side Chain of Mouse DMP1 by Substituting Critical Amino Acid Residues

Peng, T.; Huang, B.; Sun, Y. (Dallas, Tex.); Lu, Y.; Bonewald, L. (Kansas City, Mo.); Chen, S. (San Antonio, Tex.); Butler, W.T.; Feng, J.Q.; D’Souza, R.N.; Qin, C. (Dallas, Tex.)

198 Fibromodulin-Deficient Mice Reveal Dual Functions for Fibromodulin in Regulating Dental Tissue and Alveolar Bone Formation

Goldberg, M. (Montrouge); Ono, M. (Bethesda, Md.); Septier, D.; Bonnefoix, M. (Montrouge); Kilts, T.M.; Bi, Y.; Embree, M. (Bethesda, Md.); Ameye, L. (Lausanne); Young, M.F. (Bethesda, Md.)

203 Functional Roles of Prolines at Amelogenin C Terminal during Tooth Enamel Formation

Zhu, L.; Tanimoto, K.; Le, T.; DenBesten, P.K.; Li, W. (San Francisco, Calif.)

207 Immunogold Labeling of Amelogenin in Developing Porcine Enamel Revealed by Field Emission Scanning Electron Microscopy

Du, C.; Fan, D.; Sun, Z.; Fan, Y.; Lakshminarayanan, R.; Moradian-Oldak, J. (Los Angeles, Calif.)

212 Detection of Dental Fluorosis-Associated Quantitative Trait Loci on Mouse Chromosomes 2 and 11

Everett, E.T.; Yan, D. (Chapel Hill, N.C.); Weaver, M.; Liu, L.; Foroud, T.; Martinez-Mier, E.A. (Indianapolis, Ind.)

219 Dentin Noncollagenous Matrix Proteins in Familial Hypophosphatemic Rickets

Gaucher, C.; Boukpessi, T. (Montrouge/Paris); Septier, D. (Montrouge); Jehan, F. (Paris); Rowe, P.S. (Kansas City, Kans.); Garabédian, M. (Paris); Goldberg, M. (Montrouge); Chaussain-Miller, C. (Montrouge/Paris)

224 Human and Mouse Enamel Phenotypes Resulting from Mutation or Altered Expression of AMEL, ENAM, MMP20 and KLK4

Wright, J.T. (Chapel Hill, N.C.); Hart T.C.; Hart, P.S. (Bethesda, Md.); Simmons, D.; Suggs, C.; Daley, B. (Chapel Hill, N.C.); Simmer, J.; Hu, J. (Ann Arbor, Mich.); Bartlett, J.D. (Boston, Mass.); Li, Y.; Yuan, Z.-A. (Philadelphia, Pa.); Seow, W.K. (Brisbane, Qld.); Gibson, C.W. (Philadelphia, Pa.)
230 Phenotype Characterization and DSPP Mutational Analysis of Three Brazilian Dentinogenesis Imperfecta Type II Families Acevedo, A.C.; Santos, L.J.S.; Paula, L.M. (Brasilia); Dong, J.; MacDougall, M. (Birmingham, Ala.)

237 Genetic Variation in Mouse Femoral Tissue-Level Mineral Content Underlies Differences in Whole Bone Mechanical Properties

Courtland, H.-W.; Spevak, M.; Boskey, A.L.; Jepsen, K.J. (New York, N.Y.)

241 Tissue Engineering Models of Human Digits: Effect of Periosteum on Growth Plate Cartilage Development Landis, W.J.; Jacquet, R.; Lowder, E. (Rootstown, Ohio); Enjo, M.; Wada, Y.; Isogai, N. (Rootstown, Ohio/Osaka)

245 Identification of Peptides with Targeted Adhesion to Bone-Like Mineral via Phage Display and Computational Modeling

Segvich, S.; Biswas, S.; Becker, U.; Kohn, D.H. (Ann Arbor, Mich.)

252 Cell Derived Hierarchical Assembly of a Novel Phosphophoryn-Based Biomaterial

Li, J.; Olton, D.; Lee, D.; Kumta, P.N.; Sfeir, C. (Pittsburgh, Pa.)

256 The Derivation of Mesenchymal Stem Cells from Human Embryonic Stem Cells

Brown, S.E.; Tong, W.; Krebsbach, P.H. (Ann Arbor, Mich.)

261 Enamel Tissue Engineering Using Subcultured Enamel Organ Epithelial Cells in Combination with Dental Pulp Cells Honda, M.J.; Shinmura, Y.; Shinohara, Y. (Tokyo)

268 Isolation of Distinct Progenitor Stem Cell Populations from Dental Pulp

Waddington, R.J.; Youde, S.J.; Lee, C.P.; Sloan, A.J. (Cardiff)

275 Osteonecrosis of the Jaw: An Update and Review of Recommendations

Novince, C.M.; Ward, B.B.; McCauley, L.K. (Ann Arbor, Mich.)

284 Bisphosphonate-Related Osteonecrosis of the Jaw: Model and Diagnosis with Cone Beam Computerized Tomography Barragan-Adjemian, C.; Lausten, L.; Ang, D.B.; Johnson, M.; Katz, J.; Bonewald, L.F. (Kansas City, Mo.)

289 Bisphosphonates and Osteonecrosis of the Jaw: Moving from the Bedside to the Bench

Allen, M.R. (Indianapolis, Ind.)

295 Abstracts of Poster Presentations

303 Author Index

304 Subject Index

306 Conference Calendar

No. 5

Original Papers

307 Chondrogenic Potential of Mesenchymal Stem Cells from Patients with Rheumatoid Arthritis and Osteoarthritis: Measurements in a Microculture System

Dudics, V.; Kunstár, A.; Kovács, J.; Lakatos, T.; Géher, P.; Gömör, B. (Budapest); Monostori, Ė. (Szeged); Uher, F. (Budapest)

317 Influence of Platelet-Rich Plasma on Chondrogenic Differentiation and Proliferation of Chondrocytes and Mesenchymal Stem Cells

Drengk, A.; Zapf, A.; Stürmer, E.K.; Stürmer, K.M.; Frosch, K.-H. (Göttingen)

327 Prefabrication of Vascularized Porous Three-Dimensional Scaffold Induced from rhVEGF 165: : A Preliminary Study in Rats Yang, P.; Wang, C.; Shi, Z.; Huang, X.; Dang, X.; Xu, S.; Wang, K. (Xian)

338 Nestin Expression Reflects Formation, Revascularization and Reinnervation of New Myofibers in Regenerating Rat Hind Limb Skeletal Muscles

Č́̌žková, D. (Hradec Kralove); Soukup, T. (Prague); Mokrý, J.

(Hradec Kralove) 
348 Novel System for Degeneration of Blood Vessels by UV Irradiation and Subsequent Regeneration Using Chick Bone Marrow Cells

Usui, F.; Yamamoto, Y. (Nagano); Nakamura, Y. (Nagano/Ibaraki); Ono, T.; Kagami, H. (Nagano)

356 Molecular Characterization of Human Impacted Third Molars: Diversification of Compartments

Schoenebeck, B.; Hartschen, H.J.; Schindel, M.; Degistirici, O.;

Siemonsmeier, J.; Goetz, W.; Thie, M. (Bonn)

371 Patent Watch

372 Conference Calendar

\section{No. 6}

Original Papers

373 Ascorbic Acid Enhances Adipogenesis of Bone MarrowDerived Mesenchymal Stromal Cells

Weiser, B.; Sommer, F.; Neubauer, M.; Seitz, A.; Tessmar, J.; Goepferich, A.; Blunk, T. (Regensburg)

382 Enrichment of Human $\beta_{1}{ }^{\text {bri }} / \alpha_{6}{ }^{\text {bri }} / C D 71^{\text {dim }}$ Keratinocytes after Culture in Defined Media

Lorenz, K.; Rupf, T.; Salvetter, J.; Bader, A. (Leipzig)

391 Chondroitin Sulphate-Mediated Fusion of Brain Neural Folds in Rat Embryos

Alonso, M.I.; Moro, J.A.; Martín, C.; de la Mano, A.; Carnicero, E.

(Valladolid); Martínez-Álvarez, C. (Madrid); Navarro, N.; Cordero, J.

Gato, A. (Valladolid)
403 Expression of Collagen Types I, II and III in Juvenile Angiofibromas

Gramann, M.; Wendler, O.; Haeberle, L.; Schick, B. (Erlangen)

410 Striated Myogenesis and Peristalsis in the Fetal Murine Esophagus Occur without Cell Migration or Interstitial Cells of Cajal

Rishniw, M.; Fisher, P.J.; Doran, R.M.; Bliss, S.P.; Kotlikoff, M.I. (Ithaca, N.Y.)

420 Cell Surface Immobilization of GABAARs in Cerebellar Granule Cells Depends on the M3/M4 Cytoplasmatic Loop of the Alpha 1 Subunit

Perán, M. (Jaén/Granada); Hooper, H. (Newcastle); Marchal, J.A.; Boulaiz, H (Granada); Rodríguez-Serrano, F.; Velez, C. (Jaén/Granada); Aránega, A. (Granada); Salas, R. (Houston, Tex.)

425 Patent Watch

426 Conference Calendar

427 Author Index Vol. 189, 2009

428 Subject Index Vol. 189, 2009

\section{S. Karger}

Medical and Scientific Publishers

Basel $\cdot$ Freiburg $\cdot$ Paris $•$ London •

New York $\cdot$ Bangalore $\cdot$ Bangkok $•$

Shanghai $\cdot$ Singapore $\cdot$ Tokyo $\cdot$ Sydney
Disclaimer

The statements, opinions and data contained in this publication are solely those of the individual authors and contributor and not of the publisher and the editor(s). The appearance of advertisements in the journal is not a warranty, endorsement, or approval of the products or services advertised or of their effectiveness, quality or safety. The publisher and the editor(s) disclaim responsibility for any injury to persons or property resulting from any ideas, methods, instructions or products referred to in the content or advertisements.

Drug Dosage

The authors and the publisher have exerted every effort to ensure that drug selection and dosage set forth in this text are in accord with current recommendations and practice at the time of publication. However, in view of ongoing research, changes in government regulations, and the constant flow of information relating to drug therapy and drug reactions, the reader is urged to check the package insert for each drug for any change in indications and dosage and for added warnings and precautions. This is particularly important when the recommended agent is a new and/or infrequently employed drug.
All rights reserved.

No part of this publication may be translated into other languages, reproduced or utilized in any form or by any means, electronic or mechanical, including photocopying, recording microcopying, or by any information storage and retrieval system, without permission in writing from the publisher or in the case of photocopying, direct payment of a specified fee to the Copyright Clearance Center (see 'General Information').

(C) Copyright 2009 by S. Karger AG,

P.O. Box, CH-4009 Basel (Switzerland)

Printed in Switzerland

on acid-free and non-aging paper (ISO 9706) by

Reinhardt Druck, Base 